Wiktor OWSIAK

Wyższa Szkoła Zarządzania Personelem w Warszawie

Olha PROKOPIV

Katolicki Uniwersytet Lubelski

\title{
Wybrane aspekty ustrojowe samorządu terytorialnego na Ukrainie i w Polsce
}

\section{Postawienie problemu}

$\mathrm{O}$ d 1989 roku Polska inicjowała wiele reform, których efekty postrzegane są jako przykład udanej transformacji społecznej i ustrojowo-administracyjnej. Istotne znaczenie miał proces odchodzenia od nakazowo-rozdzielczego zarządzania gospodarką oraz wcześniej przeprowadzone zmiany w sferze polityki. Polegały one na odrzuceniu przez polskie społeczeństwo dyktatury partii komunistycznej i akceptacji wielopartyjności. $Z$ dużą uwagą śledzono dokonującą się w Polsce wielką reformę administracyjną polegająca na umiejętnym połączeniu centralizacji i decentralizacji. Znalazło to swój wyraz przede wszystkim w restytucji samorządu terytorialnego. Mimo dużych trudności, dorobek wypracowany w dziedzinie zarządzania sprawami publicznymi stanowi trudny do przeniesienia wzór dla praktycznej implementacji idei i zasad demokratycznego państwa prawa. Doświadczenia Polski mogą służyć jako wzorzec przemian, odpowiadający uwarunkowaniom społeczno-ekonomicznym państw byłego bloku wschodniego, w tym Ukrainie.

Budowa nowej, jednoczącej się Europy na zasadach wielostronnego związku narodowo-politycznych oraz finansowo-ekonomicznych systemów wymaga unifikacji głównych parametrów funkcjonowania tych systemów w państwach, które się integrują. Szczególnie ostro problem ten zarysował się przed postkomunistycznymi państwami Centralnej i Wschodniej Europy, które znajdowały się i są na różnych etapach rozwoju wchodzenia do struktur Unii Europejskiej.

Istotnym warunkiem przyspieszenia procesu integracyjnego jest formowanie strukturalnego, elastycznego systemu władzy, który odpowiadałby europejskim standardom. Istotne miejsce w funkcjonowaniu mechanizmu władzy w państwach Europy posiada administracja samorządowa, która 
zgodnie z Europejską Kartą Samorządu Terytorialnego jest jednym z głównych fundamentów demokracji, zabezpieczającym realne zaangażowanie każdego obywatela do zarządzania-administrowania ekonomicznym i społecznym rozwojem terytorialnej wspólnoty, która jest podstawową komórką państwowego organizmu.

Lokalne wspólnoty terytorialne są najmniejszymi administracyjno-terytorialnymi częściami państwa. Jej mieszkańcy stanowią terytorialną gminę w Polsce (hromadę - na Ukrainie), są upoważnieni bezpośrednio bądź poprzez przedstawicielskie organy do efektywnego podejmowania decyzji o znaczeniu lokalnym oraz powinny zabezpieczyć realizowanie jakościowych usług w sferze publicznej. Ustrój oraz funkcjonowanie tych wspólnot daje możliwość organom rządowej administracji koncentrować swój wysiłek na rozwiązywanie ogólnych, narodowych, makroekonomicznych decyzji, nie obciążając siebie lokalnymi problemami. Proces rozwoju terytorialnych wspólnot jest podstawowym warunkiem nowego ustroju administracyjnego państw Europy w warunkach toczącego się procesu kontynentalnej oraz światowej globalizacji.

Zadeklarowanie przez Ukrainę prawa samorządowego hromadom (gminom) nie jest wystarczającym działaniem na rzecz rozwoju samorządu terytorialnego. Państwo powinno stworzyć cały szereg warunków, umożliwiających efektywne działanie samorządu. Zdaniem W. Krawczenko w sposób najbardziej optymalny samorządność rozwija się, gdy charakteryzuje się następującymi cechami:

- liczba członków terytorialnej hromady jest nie mniejsza od minimalnie możliwego poziomu, a w tym fachowcy Banku Światowego obliczyli na 5-6 tys. osób;

- finansowa autonomia - oznacza, że terytorialna wspólnota została wyposażona w finansowe zasoby dla wykonywania własnych zadań, skierowanych na udzielenie socjalnych usług mieszkańcom, na poziomie nie mniejszym od ustanowionych przez państwo minimalnych standardów socjalnych. Terytorialna wspólnota winna być zdolna do skierowania części tych zasobów do budżetu, którego środki materialne wykorzystywane są na zabezpieczenie wykonania programu rozwoju ekonomicznego i społecznego hromady. Istnienie wystarczających zasobów finansowych daje możliwość utrzymania przez terytorialną wspólnotę niezbędnej liczby podmiotów własności komunalnej, które stanowią materialną bazę samorządu terytorialnego;

- organizacyjno-prawna niezależność. Cecha ta wskazuje na prawo hromady do utworzenia organów samorządu, które w ramach działalności 
na ustawodawczym polu państwa są niezależne od organów rządowej administracji, a przy wykonaniu własnych zadań, samodzielnie wyznaczają swoją strukturę i przyjmują uchwały, skierowane na rozwój swego terytorium;

- państwowa pomoc i ochrona. Państwo, jako instytucja zabezpiecza ogólny rozwój kraju, powinno ono prawnymi i finansowo-ekonomicznymi zasobami zagwarantować zrównoważony rozwój wszystkich terytorialnych hromad, zabezpieczać sądową ochronę przestrzegania ich konstytucyjnych praw;

- systemowa całość. Administracyjno-terytorialna jednostka najniższego poziomu nie może być sztucznie wyodrębnioną częścią kraju. Powinna ona posiadać oznaki mikroregionu jako całości terytorialno-przyrodniczych, demograficzno-socjalnych oraz ekonomiczno-gospodarskich komponentów, utworzonej z uwzględnieniem kryteriów historycznych, narodowo-etnicznych oraz społeczno-ekonomicznych ${ }^{1}$.

Takimi zasadami kierują się też państwa Unii Europejskiej, wyznaczając specyfikę oraz standardy rozwoju lokalnego. Takie standardy winny spełniać państwa kandydujące do wstąpienia do Unii Europejskiej.

Biorąc pod uwagę powyższe wytyczne, warto przeprowadzić analizę rozwoju lokalnych wspólnot terytorialnych na Ukrainie w kontekście koniecznej adaptacji samorządu do europejskich standardów poprzez porównanie tego procesu z przykładem rozwoju gmin w Polsce. Wybór ten jest spowodowany tym, że Polska od 2004 roku jest pełnoprawnym członkiem UE, jest najbliższym sąsiadem Ukrainy oraz miała podobne wyjściowe polityczne i społeczno-ekonomiczne warunki postkomunistycznego rozwoju.

Jednakże wieloaspektowa relacja samorządu do państwa, pewna odmienność kulturowa, tradycje i różne zaangażowanie w działalność wspólnot terytorialnych warunkuje istotne różnice w rozwoju lokalnym samorządu terytorialnego na Ukrainie, jak i w Polsce. W tym kontekście istotnym jest ocenić historyczne, kulturowe oraz organizacyjno-prawne przesłanki transformacji hromad na Ukrainie, ich stan obecny, specyfikę administracyjnych reform, finansową bazę, ich relacje z rejonem i obwodem oraz nadzór państwowy.

1 В. І. Кравченко, Місцеві фінанси Украӥни. Навчальний посібник, Wydawnictwo „Знання”, Kijów 1999, s. 87-90. 


\section{Kierunki rozwoju samorządu w Polsce i na Ukrainie}

W ostatnim dziesięcioleciu XX stulecia przeprowadzono administracyjne reformy w Polsce i na Ukrainie. Reformy te były skierowane na zmianę oraz udoskonalenie systemu wewnętrznego ustroju w obu państwach. Długotrwały okres braku programu reformy administracyjnej na Ukrainie (jej koncepcja była przyjęta dopiero w 1998 roku) spowodował chaotyczność oraz bezsystemowość w reformowaniu lokalnej władzy, zaczynając od 1990 roku. Struktura oraz kompetencje organów samorządu terytorialnego do czasu przyjęcia Konstytucji Ukrainy sukcesywnie były regulowane czterema, często wzajemnie sprzecznymi, ustawodawczymi aktami. Dopiero przyjęcie 28 czerwca 1996 roku Konstytucji Ukrainy, zatwierdzonej 21 maja 1997 roku ustawy o samorządzie terytorialnym na Ukrainie oraz ratyfikacja Europejskiej Karty Samorządu Terytorialnego stworzyły fundament stabilności w stanowieniu demokratycznego systemu samorządu terytorialnego. W rozdziale XI Konstytucji Ukrainy, w art. 140 określono pojęcie i istotę samorządu lokalnego. „Samorząd jest prawem terytorialnych hromad - mieszkańców wsi lub dobrowolnego zrzeszenia w gminę wiejską mieszkańców kilku wsi, miasteczek i miast - do samodzielnego rozwiązywania spraw mających znaczenie lokalne w ramach Konstytucji i ustawodawstwa Ukrainy. Samorząd lokalny realizuje się przez społeczność zgodnie z prawem, zarówno bezpośrednio, jak i przez organy samorządu lokalnego: rady wiejskie, miasteczkowe, miejskie i ich organy wykonawcze" ${ }^{2}$. Ustawa o samorządzie terytorialnym w art. 5 określa elementy systemu samorządu terytorialnego, do którego wchodzą: hromada terytorialna; wiejska, miasteczkowa, miejska rada; wiejski, miasteczkowy, miejski przewodniczący; organy wykonawcze wiejskiej, miasteczkowej i miejskiej rady; oraz rejonowe i obwodowe rady, które realizują wspólne interesy hromad terytorialnych miast, miasteczek i wsi; oraz organy samoorganizacji mieszkańców ${ }^{3}$. Ustawa samorządowa nie rozgraniczała precyzyjnie kompetencji organów samorządu terytorialnego i organów rządowej administracji, co spowodowało powstanie konfliktów w ich relacjach. Ustawa jedynie ogólnie określiła kompetencje miejscowych rad oraz ich wykonawczych organów, nie uwzględniając

2 Art. 140 Konstytucji Ukrainy, Strona Rady Najwyższej Ukrainy, www.rada.gov.ua/const/const1.

3 Ustawa o samorządzie terytorialnym na Ukrainie, Strona Rady Najwyższej Ukrainy, www.zakon.rada.gov.ua. 
różnych możliwości zasobów oraz obiektywnych potrzeb wiejskich rad z ludnością do kilku setek osób i „miast - milionerów”.

Inną drogę w procesie reformowania lokalnej władzy wybrała Polska. Proces ten odznaczał się postępowością oraz programowością transformacyjnych kroków centralnej władzy. Wznowienie działalności samorządu terytorialnego zostało poprzedzone uchwaleniem czterech aktów prawnych, dwa pierwsze z 29 grudnia 1989 r. i 8 marca 1990 r., dotyczyły nowelizacji Konstytucji Rzeczypospolitej Polskiej. Kolejnymi były ustawy z 8 marca 1990 r. o samorządzie terytorialnym i ordynacji wyborczej do rad gminnych. Ostatnia ustawa zlikwidowała system organów jednolitej administracji państwowej. Ideą przewodnią, na której oparło się ustawodawstwo polskie z 1990 roku była klasyczna koncepcja liberalistyczna samorządu terytorialnego, uzupełniana zasadą pomocniczości. Reforma administracji państwa polegała nie na całkowitym zerwaniu z centralizmem, lecz na zrównoważeniu, obu rodzajów administrowania państwowego opartego na centralizmie i decentralizacji. Ustawodawca wprowadził dualizm administracyjny.

W pierwszym etapie reformy w Polsce w 1990 roku samorząd terytorialny został przywrócony na jego najniższy poziom lokalny, który otrzymał nazwę gmina. Poziom ten jest terytorialną wspólnotą ludzi, która zamieszkała na określonym terytorium oraz jest w stanie decydować o miejscowych problemach.

Gminę wiejską i miejską ustawodawca określił jako ,podstawową jednostkę życia publicznego wyposażoną w osobowość prawną, własne mienie, odrębny budżet, z wyznaczonymi zadaniami i samodzielną, powstałą w drodze wolnych wyborów władzą lokalną, poddanąjednynie nadzorowi państwa"4. Według J. Regulskiego wprowadzenie samorządu terytorialnego stworzyło podstawy demokratyzacji, łamiąc przy tym pięć podstawowych monopoli państwa komunistycznego: monopol polityczny partii, monopol jednolitej władzy państwowej, monopol własności państwowej, monopol polityki finansowej, monopol administracji państwowej ${ }^{5}$. Jeżeli przeanalizować dokonane reformy na Ukrainie, to złamane zostały tylko 3 monopole, a mianowicie: monopol polityczny - przez dopuszczenie innych równoprawnych podmiotów, monopol jednolitej władzy państwo-

4 S. Wójcik, Samorząd terytorialny w Polsce w XX wieku, RW KUL, Lublin 1999, S. 280 .

5 J. Regulski, ABC samorzadu terytorialnego - poradnik nie tylko dla radnych, http://www.frdl.org.pl/wydawnic/publikacje.htm. 
wej - przez likwidacje zasady hierarchicznego podporządkowania władz lokalnych władzom centralnym i monopol własności państwowej - przez przekazanie znacznej części własności państwa gminom, jako mienia komunalnego, czyniąc je podmiotami prawa cywilnego. Nie został złamany monopol polityki finansowej i podporządkowanie służbom administracji rządowej.

Przywrócenie samorządu terytorialnego po upływie ponad 70 lat na Ukrainie i 50 lat w Polsce wymagało podjęcia poważnego wysiłku legislacyjnego i organizacyjnego. W Polsce od 1990 do 1998 roku uruchomiono proces prawnego uzupełnienia i funkcjonowania gminy. Sukcesy w formowaniu prawnej i finansowo-ekonomicznej zdolnej do działania gminy, pozwoliły Polsce w 1999 r. przeprowadzić kompleksową administracyjną reformę, która dała możliwość wprowadzenia trzypoziomowego systemu samorządu terytorialnego, stworzenia terytorialnych zjednoczeń typu regionalnego, które odpowiadają pojęciu ,region” w Unii Europejskiej. Poprzez ścisłe rozgraniczenie kompetencji poszczególnych poziomów samorządu terytorialnego, doprowadzono do ustalenia roli rządowej administracji tylko do wykonania kontrolno-nadzorczej funkcji. Przeprowadzenie tej reformy poprzedziło przyjęcie w 1998 r. pakietu ustaw o funkcjonowaniu samorządu terytorialnego na poziomie powiatu i województwa. W dniu 5 czerwca 1998 r. uchwalono ustawy o samorządzie wojewódzkim i powiatowym ${ }^{6}$. Na Ukrainie natomiast jedyną ustawą dla trzech szczebli samorządu jest ustawa o samorządzie terytorialnym na Ukrainie z 1997 roku, która określa kompetencje wszystkich podmiotów samorządu terytorialnego. Prześledzenie administracyjnych przekształceń w Polsce pokazuje, że Polska znacznie wyprzedza Ukrainę w procesie stanowienia pełnowartościowego samorządu terytorialnego.

\section{Ograniczenia w rozwoju}

Ukraina i Polska znacznie różnią się w liczebności, rozmiarach oraz liczbie mieszkańców terytorialnych wspólnot na poziomie lokalnym (Tab. 1).

Liczebność gmin, które są podstawowymi jednostkami samorządu terytorialnego wynosi w Polsce 2478 (w tym miast na prawach powiatu). $\mathrm{Na}$ Ukrainie obecnie odpowiednio jest 11340 terytorialnych hromad. Wiel-

6 Dz. U. Nr 91, poz. 576 i 578. 
kość tych jednostek można określić m.in. poprzez powierzchnię zajmowanego obszaru lub liczbę ludności. Ta druga miara jest zdecydowanie ważniejsza, jako, że liczba ludności z jednej strony tworzy popyt na usługi publiczne, a z drugiej wpływa w sposób bezpośredni (podatki) lub pośredni (metoda kalkulowania dotacji, subwencji) na kształtowanie się potencjału finansowego tych jednostek.

Tabela 1

Charakterystyka wspólnot terytorialnych lokalnego poziomu na Ukrainie i w Polsce

\begin{tabular}{||l|c|c||}
\hline \multirow{2}{*}{$\begin{array}{c}\text { Nazwa podstawowej jednostki samorządu lo- } \\
\text { kalnego }\end{array}$} & $\begin{array}{c}\text { Ukraina } \\
\text { wioska albo ich zjednoczenie, } \\
\text { miasteczko oraz miasto }\end{array}$ & gmina \\
\hline Powierzchnia państwa, tys. km² & 603,7 & 312,7 \\
\hline Liczebność ludności, stan na 1.01.2008, mln & 46,3 & 38,1 \\
\hline $\begin{array}{l}\text { Liczebność lokalnych wspólnot terytorialnych, } \\
\text { stan na 1.01.2008 }\end{array}$ & 11340 & 2478 \\
\hline $\begin{array}{l}\text { Średnia powierzchnia lokalnych wspólnot tery- } \\
\text { torialnych, w km }\end{array}$ & 53,2 & 126,2 \\
\hline $\begin{array}{l}\text { Średnia liczebność ludności w lokalnych wspól- } \\
\text { notach terytorialnych, w tys. }\end{array}$ & 4,1 & 15,3 \\
\hline
\end{tabular}

Źródlo: Strony internetowe Rady Najwyższej Ukrainy i GUS.

Jak widać z danych umieszczonych w tabeli, lokalne społeczności terytorialne na Ukrainie są 2,4 razy mniejsze niż w Polsce ze względu na powierzchnię oraz 3,7 razy ze względu na liczebność ludności. Oprócz tego nawet wliczając istnienie dużych miejskich terytorialnych hromad, średnia liczebność mieszkańców w terytorialnych wspólnotach lokalnego poziomu nie odpowiada minimalnemu poziomowi, o którym była mowa wyżej. Na terytorium Ukrainy istnieje 10623 wiejskich hromad, które w większości są złożone z jednej bądź dwóch wiosek oraz jednoczą mniej niż tysiąc mieszkańców. Takie hromady są skazane na funkcjonalną porażkę. Nie są zdolne zebrać odpowiednich środków finansowych, materialnych i ludzkich zasobów dla wykonania swych funkcji oraz zadań, wyznaczonych im ustawą.

Konstytucja Ukrainy w pewien sposób sprzyja zwiększeniu terytorialnych hromad, art. 140 Konstytucji dopuszcza zjednoczenie mieszkańców kilku wiosek w jedyną terytorialną hromadę w celu realizacji samorządu lokalnego i wyboru wspólnych samorządowych organów. Natomiast nie ma już możliwości żeby miasto i wioski zjednoczyły się albo miasteczka 
z wioskami, gdyż nie jest to przewidziane przez normy ustawodawcze. Tym samym Konstytucja zablokowała proces integracji miejskich, miasteczkowych i wiejskich hromad i stworzyła sztuczną prawną barierę w tworzeniu efektywnej społeczności terytorialnej.

\section{Wladze podstawowych jednostek samorządu terytorialnego}

Gminnym parlamentem w Polsce, tj. organem stanowiącym i kontrolnym jest rada gminy, jest to kolegialny organ, kadencja którego określona jest na cztery lata. Rada gminy jest powoływana przez społeczność lokalną przez wybory. Pochodzi ona z demokratycznych, pięcioprzymiotnikowych wyborów, tj. wolnych, powszechnych, równych, bezpośrednich i tajnych. Czynne i bierne prawo wyborcze przyznano osobom, które ukończyły 18 lat i są obywatelami polskimi. Szczegółowe zasady ich przeprowadzania określa ordynacja wyborcza do rad gmin, powiatów i województw samorządowych ${ }^{7}$. Rada gminy, licząc od 15 do 45 radnych, podejmuje uchwały we wszystkich sprawach pozostających w zakresie działania gminy, o ile ustawa nie stanowi inaczej. Pracami rady kieruje przewodniczący, którego rada wybiera w głosowaniu tajnym ze swego grona (art.19, ust.1). Natomiast „rządem”, czyli organem wykonawczym jest - powołany przez wybory bezpośrednie na podstawie odrębnych przepisów - odpowiednio wójt, burmistrz bądź prezydent ${ }^{8}$. Jako jednoosobowy organ wykonawczy gminy kieruje bieżącymi sprawami gminy i reprezentuje ją na zewnątrz. Wójt (burmistrz, prezydent miasta) wykonuje swoje zadania z pomocą urzędu gminy (miasta). W zakresie zadań własnych podlega on wyłącznie radzie gminy.

Na Ukrainie również występują lokalne rady (wiejska, miasteczkowa i miejska), jako przedstawicielskie organy:

- są to organy, wybrane bezpośrednio przez wspólnotę terytorialną w tajnych, bezpośrednich wyborach;

- akumulują interesy wspólnot terytorialnych i mają prawo do ich przedstawicielstwa;

- mają prawo przyjmować uchwałę w imieniu wspólnoty terytorialnej.

7 Dz. U. 1998, Nr 95, poz. 602 z późn. zm.

8 Ustawa z dnia 20 czerwca 2002 r. o bezpośrednim wyborze wójta, burmistrza i prezydenta miast, Dz. U. 2002, Nr 113, poz. 984. 
Kadencja rady określona jest na 4 lata. Wybory do rad są większościowe. Liczba deputowanych wynosi od 15 osób w hromadach nie przekraczających 3 tys. mieszkańców, do 120 osób w gromadach przekraczających ponad $1 \mathrm{mln}$ mieszkańców. Wydaje się, że są to ciała nazbyt liczne i obniża to ich sprawność pracy.

Organami wykonawczymi wiejskiej, miasteczkowej, miejskiej rady są ich wykonawcze komitety, działy, urzędy oraz inne stworzone przez rady wykonawcze organy. Przewodniczący (gołowa) wsi, miasteczka, miasta posiada samodzielny status, najwyższe stanowisko we wspólnocie terytorialnej wsi, miasteczka lub miasta. W wiejskich gromadach, w których liczba mieszkańców nie przekracza 500 mieszkańców, rady mogą nie tworzyć wykonawczych organów. Wtedy ich kompetencje są realizowane przez przewodniczącego wsi jednoosobowo. Przewodniczący jest wybierany przez wspólnotę terytorialną na podstawie powszechnych, bezpośrednich, tajnych wyborów zgodnie z art. 141 Konstytucji Ukrainy. Wiejski, miasteczkowy i miejski przewodniczący pełni trzy funkcje, a mianowicie: - jednoosobowo reprezentuje wspólnotę terytorialną w stosunkach z innymi wspólnotami terytorialnymi, z organami władzy państwowej, z przedsiębiorstwami, instytucjami i organizacjami;

- przewodniczy na plenarnych posiedzeniach odpowiedniej rady; - jest przewodniczącym wykonawczego komitetu odpowiedniej rady ${ }^{9}$.

Jak widać z wyżej przedstawionych funkcji, przewodniczący, jako monokratyczny organ pomocniczy, przewodniczy pracom dwóch oddzielnych organów: radzie, jako organowi przedstawicielskiemu i komitetowi wykonawczemu, jak sama nazwa wskazuje organowi wykonawczemu. Przewodniczący hromad mają silniejszą pozycję niż wójt w Polsce.

\section{Bariery ustrojowe}

W Polsce na poziomie gminy, powiatu i województwa samorząd ma swoje jasno określone funkcje, za należne wykonanie których ponoszą odpowiedzialność. Wszystkie szczeble samorządu terytorialnego są realnie niezależnymi, formują przedstawicielskie organy, które mają swoje wykonawcze struktury. Polskie państwo całkowicie przekazało funkcje z zabezpieczeniem socjalno-ekonomicznego rozwoju miejscowego terytorium.

9 Art. 141 Konstytucji Ukrainy, Strona Rady Najwyższej Ukrainy, www.rada.gov.ua/const/const1. 
Na poziomie powiatów oraz gmin nie ma organów terenowej administracji państwowej. W województwie występuje dualizm administracji publicznej - organy administracji rządowej i organy samorządu terytorialnego realizują własne kompetencje na tym samym terenie. Wojewoda jest przedstawicielem Rady Ministrów, jest zwierzchnikiem zespolonej administracji rządowej, organem nadzoru nad jednostkami samorządu terytorialnego.

Stosunki między poziomami samorządu terytorialnego w Polsce budują się na zasadzie niezależności, uwzględniając własne interesy oraz dotrzymanie strategicznych orientacji socjalno-ekonomicznego rozwoju terytorium.

Zasadnicze różnice istnieją w budowie systemu samorządu terytorialnego na Ukrainie. Faktycznie w państwie istnieje trójpoziomowy system samorządu terytorialnego (wioska albo ich zjednoczenie, miasteczko, miasto $\rightarrow$ rejon $\rightarrow$ obwód), ale na poziomie rejonu i obwodu samorząd terytorialny jest formalny: przedstawicielskie organy - rejonowe i obwodowe rady - nie mają prawa powołać swych wykonawczych struktur, których role pełnią rejonowe i obwodowe rządowe administracje. Jaśniej pokazuje strukturę administracji rządowej i samorządowej na Ukrainie schemat na rysunku 1 .

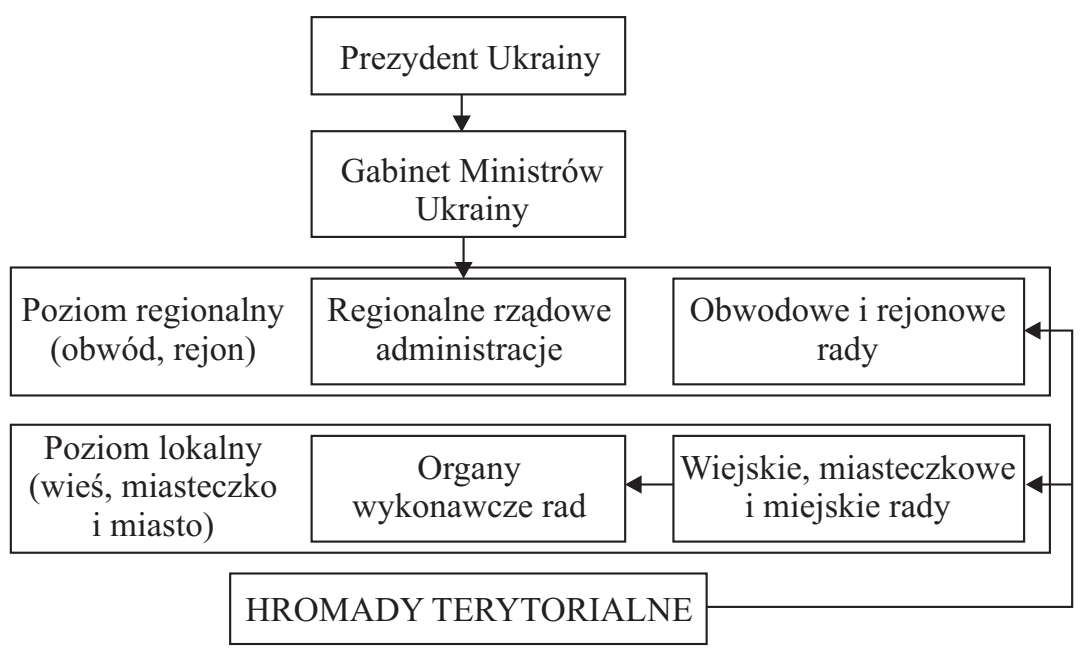

Rys. 1. Organizacja władzy na Ukrainie na lokalnym i regionalnym poziomie Źródło: T. Ivanowa, Організація місцевого самоврядування на Україні, Wydawnictwo „Професіонал", Kijów 2005, s. 34. 
Terenowe organy władzy rządowej przejęły na siebie pełnię władzy w regionie, zostawiając organom samorządu terytorialnego funkcję prawnego zatwierdzenia budżetu i kierowniczych działań organów państwowej administracji. Terytorialne wspólnoty poziomu lokalnego, na podstawie Konstytucji będąc niezależnymi, też muszą podporządkowywać się organom władzy wykonawczej, które wykonują subiektywny podział państwowych dotacji, formułują i realizują programy socjalno-ekonomicznego rozwoju terytorium.

W tej sytuacji, system władzy samorządu terytorialnego na Ukrainie jeszcze nie do końca odpowiada zasadom demokracji, subsydiarności oraz priorytetowości samorządu w podejmowaniu decyzji o znaczeniu lokalnym, które są uznawane w europejskich państwach.

\section{Materialna i finansowa baza samorządu}

W Polsce Ustawa o samorządzie gminnym w celu umożliwienia realizacji zadań samorządu wyodrębnia mienie komunalne oraz odpowiednie środki finansowe, określając zasady komunalnej gospodarki finansowej. Wskazuje sposoby nabycia majątku i określa podstawowe zasady, jak nimi dysponować. Art. 43 ust. 2 ustawy o samorządzie gminnym z 8 marca 1990 roku stanowi, że mieniem komunalnym jest własność i inne prawa majątkowe należące do poszczególnych gmin i ich związków oraz mienie innych gminnych osób prawnych, w tym przedsiębiorstw. Podstawowe zasoby mienia komunalnego powstały w wyniku przejęcia przez gminy mienia państwowego, co nazwane zostało procesem komunalizacji. Jednostki samorządu terytorialnego samodzielnie decydują o przeznaczeniu i sposobie wykorzystania składników mienia samorządowego. Samodzielność ta podlega niewielkiemu ograniczeniu - zastrzeżeniu wynikającym przede wszystkim z jego społeczno-gospodarczego przeznaczenia. Mienie komunalne jest podstawą wykonywania zadań podejmowanych przez samorząd samodzielnie, na podstawie ustawy. Drugim źródłem dochodów gmin jest komunalna gospodarka finansowa. W Polsce poszukiwanie efektywnego modelu finansowania gmin trwa od 1990 roku, kiedy przyjęto odpowiednią ustawę o dochodach gmin i zasadach ich subwencjonowania z 14 grudnia 1990 roku $^{10}$. Analiza dochodów gmin pokazuje, że na przykład, w 1999 roku miejscowe podatki i opłaty w lokalnym budże-

10 Dz. U. 1991, Nr 110, poz. 475. 
cie wynosiły 33,5\%. Główną ich część stanowi podatek od nieruchomości, 24,7\% dochodów miejscowych budżetów stanowił udział w ogólnopaństwowych podatkach i opłatach, 25,4\% - ogólna subwencja oraz 14,3\% - dotacje celowe ${ }^{11}$. Ogólna subwencja, którą otrzymuje gmina, składa się z następujących części: podstawowej, oświatowej i rekompensującej. Z części podstawowej subwencji ogólnej wydziela się rezerwę oraz kwotę wyrównawczą, która jest przekazywana tylko gminom o słabej kondycji finansowej z punktu widzenia własnych dochodów podatkowych na jednego mieszkańca gminy w stosunku do średniej liczonej dla wszystkich gmin w kraju. Natomiast część rekompensująca ma na celu zrekompensowanie gminom utraconych przez nie dochodów w przypadkach określonych ustawami. Dotacje celowe przeznaczane są na realizację zadań zleconych oraz na dofinansowanie zadań własnych gminy ${ }^{12}$.

Na podstawie art. 142 Konstytucji Ukrainy do materialnej i finansowej podstawy samorządu terytorialnego należą: ruchomy i nieruchomy majątek, dochody lokalnych budżetów, inne dochody, ziemia, naturalne zasoby, które są własnością wspólnot terytorialnych, jak również obiekty wspólnej własności, którymi zarządzają obwodowe i rejonowe rady. Znaczące miejsce w strukturze materialnego i finansowego zabezpieczenia zajmuje własność hromad terytorialnych, inaczej mówiąc własność komunalna. Pojęcie własności komunalnej na Ukrainie pierwszy raz było wprowadzono ustawą o własności z 7 lutego 1991 roku. Własność komunalna była rozpatrywana, jako rodzaj własności państwowej. Zasadniczą zmianę wprowadziła Konstytucja Ukrainy z 1996 roku, która oddzieliła własność komunalną jak samodzielną formę własności, podmiotami której są wspólnoty terytorialne: wioski, miasteczka, miasta. Ustawa o samorządzie na Ukrainie prawnie przyznała terytorialnym hromadom przekazaną im własność państwową. Ale ustawa nie rozwiązała problemu ścisłego rozgraniczenia podmiotów państwowej i komunalnej własności. Własność komunalna została dopiero uregulowana w Kodeksie Cywilnym Ukrainy z dnia 16 stycznia 2003 roku, gdzie mówi się o tym, że do komunalnej własności należy majątek, w tym środki pieniężne, które należą do wspólnoty terytorialnej ${ }^{13}$.

11 С. Слухай, Посткомуністичні трансформащії міжбюджетних відносин в краӥнах Центральної Свропи, Wydawnictwo „Лілея”, Tarnopol 2000.

12 M. Barański, Sł. Kantyka, S. Kubas, M. Kuś, Samorzqd terytorialny i wspólnoty lokalne, Wydawnictwo „KOMANDOR”, Warszawa 2007, s. 147.

13 Kodeks Cywilny Ukrainy z dnia 16 stycznia 2003 roku, Strona Rady Najwyższej Ukrainy, www.zakon1.rada.gov.ua. 
Dzisiaj organy samorządu terytorialnego w imieniu i na rachunek wspólnoty terytorialnej dysponują, korzystają i zarządzają podmiotami prawa własności komunalnej. Wykaz przedmiotów prawa własności komunalnej wyznacza odpowiednia wiejska, miasteczkowa, miejska rada. Warto podkreślić, że istnieje mienie, które odnosi się do przedmiotów wyłącznego prawa własności komunalnej, które nie mogą być wykluczone w żaden sposób, a wykaz tych przedmiotów jest ustanawiany statutem wspólnoty terytorialnej. Art. 60 p. 7 ustawy samorządowej mówi, że majątkowe operacje, które są przeprowadzane przez organy samorządu terytorialnego jako podmiot prawa własności komunalnej, nie mogą osłabiać ekonomicznych podstaw samorządu terytorialnego, zmniejszać zakresu i pogarszać warunków udzielenia usług mieszkańcom. Jest to bardzo ważna norma prawna, która stanowi niejako gwarancję własności komunalnej.

W teorii administracji publicznej podkreśla się, iż niezależność finansowa jednostek samorządu terytorialnego stanowi nie tylko podstawę ich stabilności i operatywności, ale jest przede wszystkim gwarancją ich niezależności. Jedynie podmiot dysponujący swoim własnym budżetem, który tworzy na podstawie określonych prawem źródeł dochodów, jest w stanie kreować politykę funkcjonowania swojej jednostki i w pełni realizować oczekiwania społeczności lokalnych. Finansowe zasoby terytorialnych wspólnot, podstawę których stanowią miejscowe budżety i mienie, są głównym czynnikiem zabezpieczającym stabilność samorządu terytorialnego.

Analiza procesu budowy samorządu terytorialnego na Ukrainie pokazuje, że właśnie problem formowania efektywnego miejscowego budżetu jest najostrzejszym problemem rozwoju tej instytucji. Brak wystarczających źródeł finansowej bazy dyskredytuje idee samorządu terytorialnego, robi ją deklaratywną. Miejscowe budżety 95\% wiosek, miasteczek oraz miast Ukrainy charakteryzują się niskim poziomem miejscowych podatków i opłat (od 3 do $5 \%$ bazy dochodowej) ${ }^{14}$. Zgodnie z Europejską Kartą Samorządu Terytorialnego, podatki i opłaty lokalne powinni stanowić przynajmniej część (najlepiej większą) dochodów miejscowych budżetów. Przynajmniej część zasobów finansowych społeczności lokalnych powinna pochodzić z opłat i podatków lokalnych,

\footnotetext{
14 Analityczne dane Obliczeniowej Pałaty Ukrainy, Про стан виконання місиевих бюджетів в Украӥні.
} 
których wysokość społeczności te mają prawo ustalać, w zakresie określonym ustawą ${ }^{15}$.

Kolejną różnicą sytemu finansowania gmin jest to, że państwowe subsydia są skierowane z centralnego budżetu do budżetu gmin, mijając poziom województwa i powiatu, co pozwala uniknać subiektywności i protekcjonizmu przy podziale państwowych dochodów. Natomiast na Ukrainie dotacje i subwencje z budżetu państwa są przekazywane nie bezpośrednio do organów wspólnot terytorialnych, lecz są przekazywane do obwodowych rad, które rozdzielają owe koszty między rejonowymi budżetami i budżetami miast, później dopiero rejonowe rady rozdzielają je między miejscowymi budżetami. Tak, więc występuje tutaj hierarchia przekazywania subwencji i dotacji.

\section{Nadzór nad samorządem}

Ingerencje organów państwowych w sferę samodzielności gminnej ma postać nadzoru. Konstytucja RP w art. 171 ust. 1 stanowi „Działalność samorządu terytorialnego podlega nadzorowi z punku widzenia legalności”. Ustawa o samorządzie gminnym w Polsce różnicuje kryterium nadzoru nad działalnością gminną w sprawach własnych i zleconych. Nadzór w sprawach własnych jest sprawowany wyłącznie na podstawie kryterium legalności. Zaś w sprawach zleconych nadzór sprawowany jest dodatkowo na podstawie kryterium celowości, rzetelności i gospodarności. Organami nadzoru w świetle przepisów Konstytucji oraz ustaw o samorządzie gminnym, powiatowym i wojewódzkim są: Prezes Rady Ministrów, wojewodowie, natomiast w zakresie spraw finansowych: regionalne izby obrachunkowe (RIO) ${ }^{16}$. Środki nadzoru można podzielić na: środki informacyjne, prewencyjno-ostrzegawcze i represyjne. Ustawodawca przewidział pięć form kontroli na poziomie gminy. Jeżeli organ nadzoru stwierdzi, że władze samorządowe łamią przepisy prawa, powinien przedsięwziąć środki prewencyjno-ostrzegawcze w celu przywrócenia stanu zgodnego z prawem. Ostatnia grupa środków nadzoru, to możliwość orzeczenia nieważności uchwały i wstrzymanie jej wykonania, zarządzanie

15 Art. 9, ust. 3 Europejska Karta Samorzqdu Terytorialnego.

16 A. Miszczuk, M. Miszczuk, K. Żuk, Gospodarka samorzqdu terytorialnego, PWN, Warszawa 2007, s. 48. 
zastępcze, rozwiązywanie organów gminy i ustanowienie zarządu komisarycznego ${ }^{17}$.

$\mathrm{Na}$ Ukrainie nadzór nad działalnością organów samorządu terytorialnego jest sprawowany przez władzę ustawodawczą, wykonawczą i sądową. Rada Najwyższa realizuje parlamentarny nadzór, to znaczy polityczno-prawny w formie zapytań poselskich, parlamentarnych interpelacji itd. Parlamentarny nadzór nad działalnością organów samorządu terytorialnego ma charakter zapobiegający łamaniu prawa. Na podstawie Konstytucji ogólny nadzór nad aktami samorządu terytorialnego realizuje wykonawcza władza. Prezydent Ukrainy, Rada Ministrów, terenowa administracja państwowa realizuje nadzór nad wykonaniem Konstytucji i ustaw Ukrainy przez organy samorządu terytorialnego. Nadzór sądowy nad działalnością organów samorządu jest realizowany z inicjatywy upoważnionych państwowych organów oraz osób na stanowiskach kierowniczych, obywateli oraz innych osób fizycznych i prawnych. Jeżeli uchwała organu samorządowego jest sprzeczna z Konstytucją Ukrainy lub ustawodawstwem, to organ nadzorujący ma możliwość stwierdzić nieważność uchwały.

\section{Wnioski dla Ukrainy}

1. W procesie adaptacji lokalnych wspólnot terytorialnych do europejskich standardów Ukraina powinna opierać się na doświadczeniu wysoko rozwiniętych państw Zachodniej i Centralnej Europy, uwzględniając historyczne oraz narodowe cechy państwowe.

2. Badanie genezy formowania wspólnot terytorialnych daje możliwość we współczesnej praktyce samorządu terytorialnego wykorzystać polityczno-społeczny oraz kulturowy potencjał terytorialnych hromad.

3. Transformacja podstawowych jednostek samorządu terytorialnego na Ukrainie powinna być pierwszoplanowym kierunkiem w reformowaniu administracyjno-terytorialnego ustroju Ukrainy. Wiąże się to z dokonaniem zmian w Konstytucji Ukrainy, przyjęciem ustawy o administracyjno-terytorialnym ustroju Ukrainy oraz ustawy o terytorialnej hromadzie, które by uwzględniały możliwość lokalnych wspólnot do terytorialnego i funkcjonalnego zjednoczenia w celu formowania zdolnej do życia terytorialnej hromady.

17 S. Wójcik, Samorząd terytorialny w Polsce w XX wieku, RW KUL, Lublin 1999, s. 321 . 
4. Konieczne jest przyjęcie odrębnych ustaw, które regulowałyby samorząd na poziomie rejonu i obwodu.

5. Trzeba stworzyć mechanizm powiększenia terytorialnego hromad na podstawie zainteresowania samodzielnych terytorialnych wspólnot do zjednoczenia, optymalnie połączywszy zasady demokratycznej dobrowolności oraz administracyjnej przymusowości takiego zjednoczenia w razie docelowości zjednoczenia podstawowych administracyjno-terytorialnych jednostek.

6. Rozgraniczenie kompetencji terenowych organów władzy wykonawczej oraz organów samorządu terytorialnego powinno odbywać się na podstawie wyznaczenia przejrzystych kryteriów rozgraniczenia ogólnopaństwowych oraz lokalnych usług i źródeł ich finansowania.

7. Aktywizacja współpracy zagranicznych i ukraińskich naukowców, deputowanych i urzędników organów samorządu terytorialnego w sferze państwowej administracji oraz stanowienia samorządu terytorialnego wspólnot lokalnych drogą przeprowadzenia seminariów, stażów, naukowo-praktycznych konferencji, okragłych stołów, które będą sprzyjać wypracowaniu teoretycznych zasad formowania zdolnej do życia podstawowej jednostki samorządu terytorialnego na naukowej podstawie.

8. Reformowanie finansowej bazy podstawowych terytorialnych wspólnot na Ukrainie należy orientować na podwyższenie znaczenia miejscowych podatków i opłat w dochodach miejscowych budżetów, wprowadzenie do listy miejscowych płatności ważnych podatków - podatek od nieruchomości, podatku dochodowego oraz formowanie finansowych relacji między budżetami podstawowych wspólnot terytorialnych a budżetami wyższych poziomów finansowego systemu państwa.

9. Należy zmienić stosunek organów władzy oraz środowisk naukowych do podstawowych terytorialnych wspólnot. Należy odejść od prymitywnego poziomu terytorialnego i przejść do badania wspólnot lokalnych jako złożonych socjalno-ekonomicznych systemów, które stanowią podstawę tworzenia państwa. Podstawowe terytorialne wspólnoty są wyjściowym ogniwem stabilnego rozwoju całego państwa oraz są koniecznymi elementami europejskiego integracyjnego procesu.

\section{Podsumowanie}

Patrząc na zagraniczne doświadczenia, konieczne jest stworzenie specjalnych funduszy budżetowych dla wyrównania poziomu budżetowego 
terytorium o słabej kondycji finansowej. Konieczne są działania zmierzające ku reformie podatkowego systemu w kierunku zmian w sferze lokalnych podatków dla zwiększenia zasobów lokalnych budżetów. Lokalne wpływy finansowe powinny być formowane $\mathrm{z}$ uwzględnieniem ekonomicznych, socjalnych i naturalnych zasobów regionów. Efektywne funkcjonowanie, a w tym efektywne finansowanie samorządu jest koniecznym warunkiem wejścia na ścieżkę wysokiego rozwoju gospodarczego. Stabilność gospodarcza Ukrainy jest potrzebna dla rozwoju gospodarczego Polski. Sprzyjanie rozwojowi gospodarczemu Ukrainy jest ekonomicznie uzasadnione i korzystne dla polskiej gospodarki. Polepszenie kondycji finansowej terytorialnego samorządu na Ukrainie pozwoli na przyspieszenie rozwoju społeczno-gospodarczego Ukrainy.

\section{Bibliografia}

Barański M., Kantyka Sł., Kubas S., Kuś M., Samorząd terytorialny i wspólnoty lokalne, Wydawnictwo Komandor, Warszawa 2007.

Варда Я., Клосовскі В., Острови надій: розробка стратегій локального розвиткy, Wydawnictwo Молодь, Kijów 2005.

Dolnicki B., Samorzq̨d terytorialny, Wydawnictwo Zakamycze, Kraków 2006.

Іванова Т., Організація місиевого самоврядування на Украӥні, Wydawnictwo „Професіонал", Kijów 2005.

Jakowenko N., Historia Ukrainy, Wydawnictwo IEŚW, Lublin 2000.

Кравченко В., Пітцик М., Муніципальне право Украӥни, Wydawnictwo „Атіка”, Kijów 2003.

Куйбіда В., Конституиійно-правові проблеми міського самоврядування в $У_{\kappa-}$ раїнi, Wydawnictwo „Літопис”, Львів 2001.

Miszczuk A., Miszczuk M., Żuk K., Gospodarka samorzqdu terytorialnego, Wydawnictwo PWN, Warszawa 2007.

Michałowski S., Pawłowska A., red., Samorzqd lokalny w Polsce. Społeczno-polityczne aspekty funkcjonowania, Wydawnictwo UMSC, Lublin 2004.

Nawrota B. i Pokładecki J., (red.) Samorzq̨d gminny w Polsce. Doświadczenia i perspektywy, Wydawnictwo UAM, Poznań 1999.

Погорілка В., Фрицький О. (red.), Муніципальне право Украӥни, Wyd. Юрінком Інтер, Kijów 2000.

Перспективи розвитку місиевого самоврядування: досвід України та Швеції, Kijów 1998.

Regulski J., ABC samorzqdu terytorialnego - poradnik nie tylko dla radnych, http://www.frdl.org.pl/wydawnic/publikacje.htm. 
Слухай С., Посткомуністичні трансформації міжбюджетних відносин в краӥнах Центральної Європи, Wydawnictwo „Лілея”, Tarnopol 2000.

Wójcik S., Naród Samorząd terytorialny Demokracja w III Rzeczpospolitej, Wydawnictwo TN KULJPII, Lublin 2007.

Wójcik S., Samorzą terytorialny w Polsce w XX wieku, Wydawnictwo RW KUL, Lublin 1999.

\section{Źródła:}

Europejska Karta Samorządu Terytorialnego.

Analityczne dane Obliczeniowej Pałaty Ukrainy, Про стан виконання місцевих бюджетів в Україні.

Kodeks Cywilny Ukrainy z dnia 16 stycznia 2003 roku, www.zakon1.rada.gov.ua.

Dz. U. 1991, Nr 110, poz. 475.

Konstytucja Ukrainy, www.rada.gov.ua/const/const1.

Ustawa z dnia 20 czerwca 2002 r. o bezpośrednim wyborze wójta, burmistrza i prezydenta miast, Dz. U. 2002, Nr 113, poz. 984.

Dz. U. 1998, Nr 95, poz. 602 z późn. zm.

Dz. U. Nr 91, poz. 576 i 578.

\section{Summary}

This paper presents the significance of the issues related to the activity of territorial self-government for the social and economic development of Ukraine. The efficient operation of self-government in any country is unfeasible without financial resources. Polish experience in the development of territorial self-government is particularly valuable in relation to the reform of Ukraine's self-government. The paper outlines the differences in the structure and operation of territorial self-government in both countries. The paper is concluded with numerous observations on the direction of selected reforms of Ukrainian self-government. It shows the weaknesses of local self-government in Ukraine, which result from the lack of decentralization of finance and the small amount of state-collected taxes. The conclusions end with the observation that a consistent development of the Ukrainian state is required for Poland to develop well. 